\title{
Aggregata bathytherma sp. nov. (Apicomplexa: Aggregatidae), a new coccidian parasite associated with a deep-sea hydrothermal vent octopus
}

\author{
C. Gestal $^{1, *}$, S. Pascual ${ }^{1}$, F. G. Hochberg ${ }^{2}$ \\ ${ }^{1}$ Instituto de Investigaciones Marinas, Consejo Superior de Investigaciones Científicas, Eduardo Cabello 6, \\ 36208 Vigo, Spain \\ ${ }^{2}$ Department of Invertebrate Zoology, Santa Barbara Museum of Natural History, 2559 Puesta del Sol, Santa Barbara, \\ California 93105, USA
}

\begin{abstract}
Aggregata bathytherma sp. nov. is described from the digestive tract of Vulcanoctopus hydrothermalis, a deep-sea octopus recently discovered associated with hydrothermal vents in the northeast Pacific Ocean. Oocysts typically are spherical in shape, sometimes irregular, 163 to $356 \mu \mathrm{m}$ in length, and 219 to $313 \mu \mathrm{m}$ in width. Each oocyst contains from 50 to over 200 sporocysts. Sporocysts measure 27 to $32 \mu \mathrm{m}$ in longest diameter. The cyst wall is smooth and $1 \mu \mathrm{m}$ thick. Each sporocyst typically contains 14 to 17 sporozoites, $49 \mu \mathrm{m}$ in length. Histological lesions associated with the presence of $A$. bathytherma include rupture of the basal membrane and detachment of the epithelial cells. In heavily infected areas, most of the tissue of the host digestive tract is replaced by parasites. A. bathytherma is the first Aggregata species described from a host that lives in association with hydrothermal vents, and the third species of Aggregata from eastern North Pacific waters.
\end{abstract}

KEY WORDS: Aggregata bathytherma - Vulcanoctopus hydrothermalis · Coccidian parasite . Deep-sea hydrothermal vent

\section{INTRODUCTION}

Species within the genus Aggregata are intracellular coccidian parasites with a 2-host life cycle. Sexual stages (gamogony and sporogony) occur in the digestive tracts of cephalopods, the definitive hosts, and asexual stages (merogony) in the digestive tracts of crustaceans, the intermediate hosts (Dobell 1925, Gestal et al. 2002a). The union of a microgamete and a macrogamete in the digestive tract of a cephalopod produces a zygote, which becomes an early sporont with numerous nuclei. Individual nuclei with accompanying cytoplasm later bud off, forming uninucleated spherical sporoblasts. The development of sporoblasts into sporocysts is characterized by an increase in the number of nuclei and further partitioning of nuclei- and cytoplasm-forming sporozoites. After formation and maturation, sporocysts containing infective sporozoites leave the host with the feces. In the sea sporocysts must be ingested by a suitable crustacean intermediate host to continue their life cycle. Sporocysts pass to the digestive tract of the crustacean, where they hatch as a result of the action of stomach acid, and release sporozoites. Sporozoites migrate through the midgut epithelium to the submucous connective tissue, where they grow and become meronts. Finally, meronts generate merozoites by schizogony in the same way as the sporozoites develop in the cephalopod host (Hochberg 1990, Gestal et al. 2002a). Experimental infections have concluded that coccidians of the genus Aggregata show a high degree of specificity in the definitive host; however, lower specificity was observed in the intermediate crustacean host (Gestal et al. 2002a).

To date, coccidian infections have not been reported from deep-sea invertebrates. All previous records are known from shallow-water cephalopods and pelagic 
and benthic crustaceans (Hochberg, 1990). In contrast, haematozoans have been described in deep-sea demersal fishes in the Atlantic Ocean (Khan et al. 1992), and haemogregarines infecting blood cells of Zeus capensis from deep waters of South Africa (Smit \& Davies 2006). A diversity of myxosporidians has been reported from deep-water fishes, especially macrourids, in both the Atlantic and Pacific Oceans (Yoshino \& Moser 1974, Threlfall \& Khan 1990, Lom \& Dyková 1992). With regard to crustaceans, 5 named and numerous unnamed species of Aggregata are known to occur in benthic and pelagic crustacean hosts (see Théodoridès \& Desportes 1975, Hochberg 1990). However, no data exist on the presence of coccidian parasites in deep-sea crustaceans.

Several years ago, González et al. (1998) described a new genus and species of a deep-sea octopus named Vulcanoctopus hydrothermalis. The species inhabits depths ranging from 2500 to $2700 \mathrm{~m}$ where it lives in close association with hydrothermal vents on the East Pacific Rise. Here we present morphological and morphometric characteristics on the sporogonial stages of a new species of coccidia parasite of the genus Aggregata found in this hydrothermal octopus. This is the third species of Aggregata to be described from the northeastern Pacific Ocean.

\section{MATERIALS AND METHODS}

Samples of Vulcanoctopus hydrothermalis were caught during several dives of the deep-sea manned submersible 'Alvin' at the Genesis site on the East Pacific Rise at $12^{\circ} 48.68^{\prime} \mathrm{N}, 103^{\circ} 56.39^{\prime} \mathrm{W}$. The octopod hosts were collected by a robotic arm grab at depths ranging from 2595 to $2635 \mathrm{~m}$. Host specimens were collected near a high temperature hydrothermal vent. Octopus specimens were frozen immediately following capture. In the laboratory they were fixed in $10 \%$ formalin and later transferred and preserved in $70 \%$ ethanol. Dorsal mantle length (ML), total body weight (BW), sex and stage of maturation were recorded for each octopus examined (see Table 1).

Aggregata oocysts were obtained from the digestive tracts, mainly caecum and intestine, of infected octopus previously deposited at the Santa Barbara Museum of Natural History. Squash preparations were examined by excising white cysts containing sporocysts and crushing them between 2 microslides. Sporogonial stages were measured under 100× magnification with an oil immersion objective using a calibrated ocular micrometer. All measurements are in micrometers $(\mu \mathrm{m})$ unless otherwise indicated. Paraffinembedded tissue which contained Aggregata was sectioned at $4 \mu \mathrm{m}$ and stained with hematoxylin and eosin following standard procedures (Culling et al. 1985).

\section{RESULTS}

\section{Aggregata bathytherma sp. nov.: description}

Material examined: based on the examination of 5 infected octopuses (Table 1).

Oocysts: shape typically spherical, sometimes irregular; sporocyst numbers ranged from 50 to over 200. Lengths ranged from 163 to $356 \mu \mathrm{m}($ mean $=245.6 \mu \mathrm{m})$; widths from 219 to $313 \mu \mathrm{m}($ mean $=255.0 \mu \mathrm{m})(\mathrm{n}=10$, 3 hosts).

Sporocysts: mature sporocysts large; shape subspherical to subovoid; surface smooth with thick wall $(1 \mu \mathrm{m})$. Lengths ranged from 27 to $32 \mu \mathrm{m}$ (mean $=$ $28.7 \mu \mathrm{m})$, widths from 24 to $32 \mu \mathrm{m}$ (mean $=27.9 \mu \mathrm{m})$ ( $\mathrm{n}=30,3$ hosts). Giant sporocysts not observed.

Sporozoites: number of sporozoites typically 14 to 17 per sporocysts ( $\mathrm{n}=5$, measured in 1 octopus); curled in spiral within sporocyst. Isolated sporozoites uniform in size, length $49 \mu \mathrm{m}$, width $5 \mu \mathrm{m}(\mathrm{n}=5$, measured in 1 octopus) (Fig. 1B,E,F,H,I).

\section{Taxonomic summary}

Type specimens (syntypes): histological sections of host digestive tracts containing mature sporocysts were deposited in the Santa Barbara Museum of Natural History: SBMNH 345335 (2 microslides) and SBMNH 345347 (2 microslides).

Type locality: northeastern Pacific Ocean, East Pacific Rise, Genesis site, $12^{\circ} 48.68^{\prime}$ N, $103^{\circ} 56.39^{\prime}$ W, 2595 to $2635 \mathrm{~m}$.

Table 1. Vulcanoctopus hydrothermalis specimens examined for the presence of Aggregata bathytherma sp. nov. Host octopus ordered by mantle length (ML) and body weight (BW). ++: A. bathytherma infection

\begin{tabular}{|c|c|c|c|c|c|}
\hline Sex & Maturity & $\begin{array}{l}\mathrm{ML} \\
(\mathrm{mm})\end{array}$ & $\begin{array}{l}\text { BW } \\
(\mathrm{g})\end{array}$ & Aggregata & $\begin{array}{l}\text { Host repository } \\
\& \text { catalog no. }\end{array}$ \\
\hline Female & Mature & 38 & 16.6 & ++ & SBMNH 142880 \\
\hline Male $^{\mathrm{a}}$ & Mature & 37 & 18.6 & ++ & SBMNH 142882 \\
\hline Male & Mature & $52^{\mathrm{b}}$ & 20.6 & ++ & FMNH 27864 \\
\hline Male & Mature & 45 & 21.8 & ++ & SBMNH 142881 \\
\hline Male & Mature & 53 & 30.6 & ++ & USNM 885672 \\
\hline
\end{tabular}




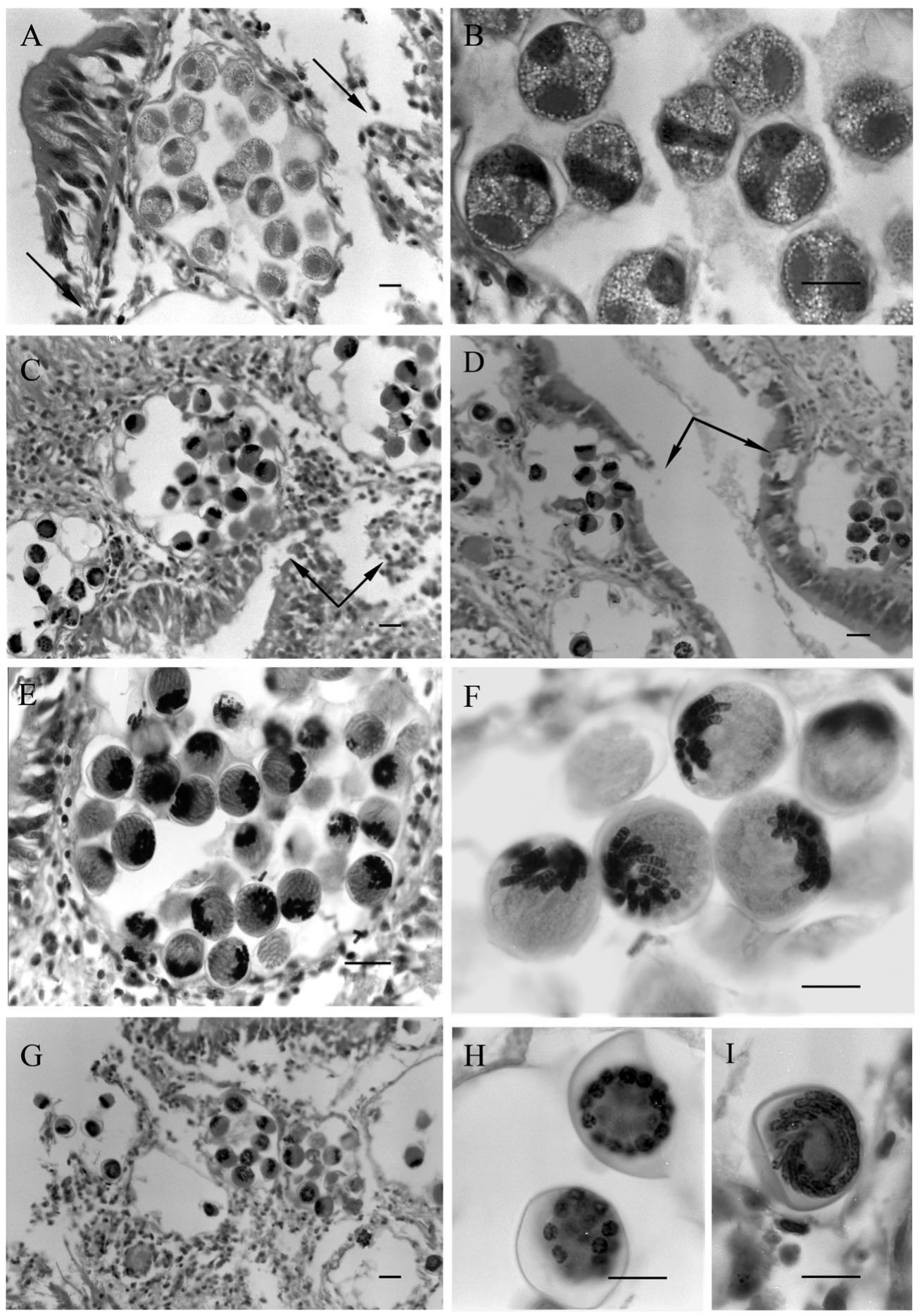

Fig. 1. Aggregata bathytherma sp. nov. Histological sections of intestine and caecum of Vulcanoctopus hydrothermalis infected by parasite. (A) Oocyst containing a sporoblast with sporozoites in formation. Arrows show rupture of infected tissue from development of the coccidian detachment and loss of epithelial cells. (B) Detail of sporoblast development and division to form sporozoites. (C, D) Caecum villous infected with parasite showing oocysts containing sporocysts and destruction of the tissue organ architecture by replacement by parasites. Arrows show distension and rupture of the basal membrane and loss of digestive tract epithelium. (E) Oocyst containing sporocysts with mature sporozoites inside. (F) Detail of mature sporocysts containing 14 to 17 sporozoites. (G) Heavily infected intestinal area showing replacement of the infected host tissue by parasites, resulting in the loss of the digestive tract epithelium and destruction of the tissue organ architecture. (H) Detail of sporozoites inside the sporocyst. Transverse section. (I) Detail of sporozoites inside the sporocyst. Longitudinal section. Scale bars: (A, C, D, E, G) $30 \mu \mathrm{m}$; (B, F, H, I) $15 \mu \mathrm{m}$ 


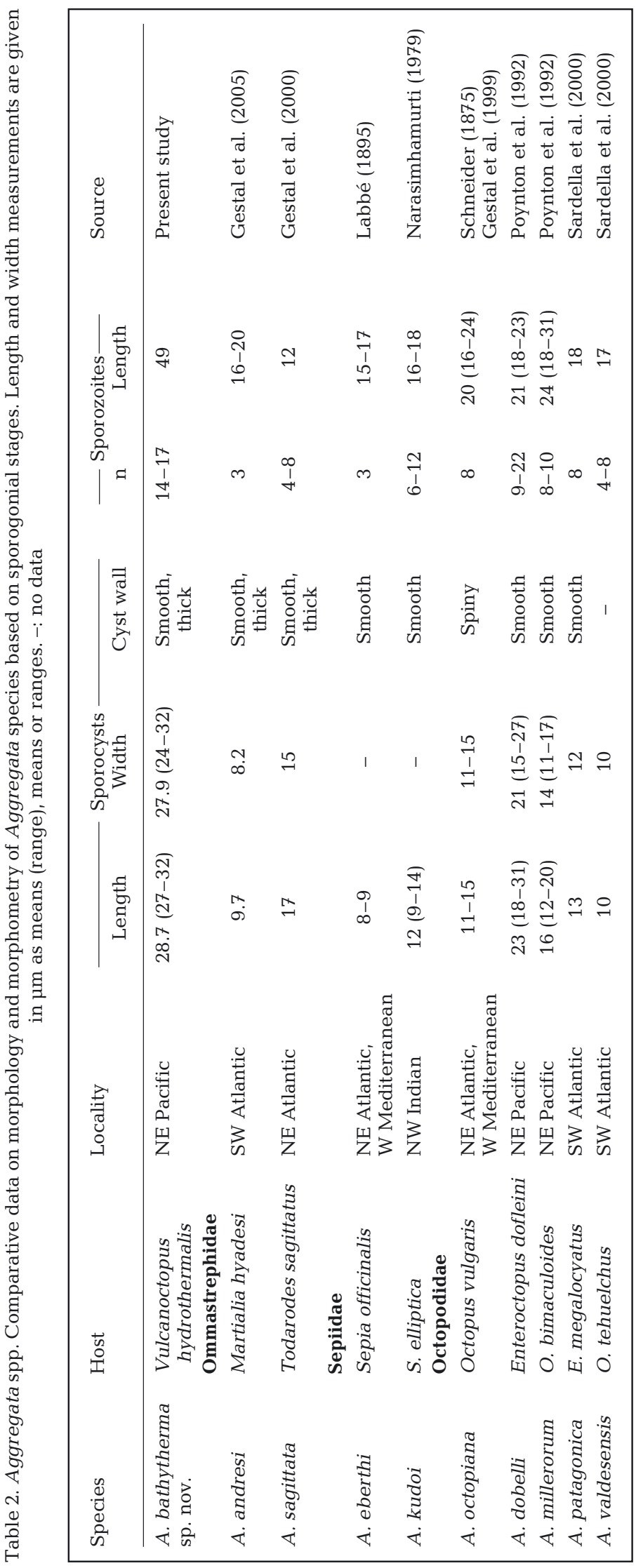

Other localities: additional material examined in the present study was collected in the region of the type locality and to the south at $9^{\circ} 50.33^{\prime} \mathrm{N}$, $104^{\circ} 17.48^{\prime} \mathrm{W}$. Cephalopod hosts were collected at depths ranging from 2512 to $2635 \mathrm{~m}$.

Symbiotype: Vulcanoctopus hydrothermalis González, Guerra, Pascual \& Briand, 1998 (González et al. 1998) (Mollusca: Cephalopoda: Octopodidae).

Symbiotype: mature male, $37 \mathrm{~mm} \mathrm{ML;} \mathrm{SBMNH}$ 142882.

Additional host vouchers: see Table 1.

Additional host species: none.

Prevalence: the infection was confirmed in all 5 hosts examined (see Table 1).

Site of infection: Sporogonial stages (sporoblasts and sporocysts containing sporozoites) were present in the intestine, spiral caecum and other non-cuticularized regions of the host digestive tract.

Etymology: the specific name is derived from the Greek word bathytherma meaning 'deep heat' in reference to the host's association with deep-sea hydrothermal vents.

\section{Histopathology}

Marked distension of the infected tissue area (intestine and caecum) due to the development of the sporogonic stages was seen, causing rupture of the basal membrane and the detachment of the epithelial cells (Fig. 1A,C,D). In heavily infected areas, most of the infected host tissue was replaced by parasites, resulting in the loss of the digestive tract epithelium and destruction of the tissue organ architecture (Fig. 1G).

\section{DISCUSSION}

At present, 9 named and several more unnamed species of Aggregata have been reported in the literature to occur in cephalopod hosts (Sardella \& Re 1988, Hochberg 1990, Poynton et al. 1992, Gestal et al. 1999, 2000, 2005). Additionally, 5 named and numerous unnamed species of Aggregata are known to occur in benthic and pelagic crustacean hosts (Théodoridès \& Desportes 1975, Hochberg 1990). Of these, only 2 species have been previously described from octopuses in the northeastern Pacific Ocean (Poynton et al. 1992); namely, A. dobelli in Enteroctopus dofleini (Wülker, 1910) and A. millerorum in Octopus bimaculoides Pickford \& McConnaughey, 1949. Furthermore, 2 other Aggregata species have been described in nerito-oceanic ommastrephid squids; namely, A. sagittata in Todar- 
odes sagittatus (Lamarck, 1798) from the northeastern Atlantic Ocean (Gestal et al. 2000) and A. andresi in Martialia hyadesi Rochebrune \& Mabille, 1889 from the southwestern Atlantic Ocean, at the Antarctic Polar Front Zone (Gestal et al. 2005).

Traditionally, diagnostic characters among species of Aggregata include phenotypic aspects related to the sporocyst structure (shape, size and thickness of the outer surface wall), number and size of sporozoites contained within the sporocysts, as well as data on host specificity (Table 2). Aggregata bathytherma sp. nov. can be distinguished from all other known species in the genus by (1) a larger sporocyst size; (2) a larger size and larger number of sporozoites in each sporocyst; and (3) a thick, smooth sporocyst wall. The latter could be an adaptation to the greater depth (i.e. higher hydrostatic pressure) to which Vulcanoctopus hydrothermalis is exposed. This characteristic has been previously reported for A. sagitattus infecting neritooceanic ommastrephid squids from the NE Atlantic (Gestal et al. 2005).

The histopathological analysis is coincident with the previously described for other Aggregata species. The damage depends upon the intensity of infection, as it is proportional to the degree of destruction of host cells (Gestal et al. 2002b). Similar to that observed in Octopus vulgaris infected by A. octopiana, the destructive effect of this parasite deduced by histopathological analysis may impair gastrointestinal functions, including the correct absorption of nutrients (Gestal et al. 2002c), and may have weakened the octopuses, making them more vulnerable to other biotic and abiotic effects.

The description of a new Aggregata species for the first time in a deep-sea cephalopod host suggests a broader habitat and distributional range than previously expected, not only for the genus Aggregata, but also for any coccidian parasite. With regard to food habits, and determining potential intermediate hosts, very little information is available. Rocha et al. (2002) indicated that Vulcanoctopus hydroythermalis likely feed on hydrothermal vent crabs Bythograea thermydron Williams, 1980. Voight (2005) reported that remains of the bathypelagic amphipod Halice hesmonectes Martin, France \& Van Dover, 1993 were found in the gut of the octopod. At present no deepsea crustaceans have been examined for the presence of Aggregata.

Although traditional identification and characterization of Aggregata species has relied primarily on differences in well-standardized morphological features such as size and shape of life-cycle stages and host specificity (Hochberg 1990), molecular techniques provide alternative methods for taxonomic studies and are important tools in solving the problems of species delimitation. The only up-to-date molecular reference refers to the nucleotide analysis of the small rDNA subunit of Aggregata species infecting the coastal cephalopods Octopus vulgaris and Sepia officinalis (Kopecná et al. 2006). Therefore, molecular sequence analysis of small and large nuclear rDNA subunits or even internal transcribed spacers should be carried out to ascertain the taxonomic status of Aggregata species within cephalopods, supporting their current classification using morphological characters, to confirm their taxonomic affiliation within the genus and to validate conservative, robust phenotypic characters useful as diagnostic tools.

Acknowledgements. We are indebted to J. J. Childress (University of California, Santa Barbara) and R. A. Lutz (Rutgers University) for collecting the octopod host specimens while on expedition to the East Pacific Rise. B. A. Seibel (University of Rhode Island), M. Sweeney (National Museum of Natural History, Smithsonian Institution) and J. R. Voight and J. Slapsinsky (Field Museum) facilitated our study by providing donations or loans of octopus host specimens.

\section{LITERATURE CITED}

Culling CFA, Allison RT, Barr WT (1985) Cellular pathology technique. Butterworth \& Co., London

$>$ Dobell CC (1925) The life history and chromosome cycle of Aggregata eberthi. Parasitology 17:1-139

Gestal C, Pascual S, Corral L, Azevedo C (1999) Ultrastructural aspects of the sporogony of Aggregata octopiana (Apicomplexa, Aggregatidae) a coccidian parasite of Octopus vulgaris (Mollusca, Cephalopoda) from NE Atlantic coast. Eur J Protistol 35:417-425

Gestal C, Guerra A, Abollo E, Pascual S (2000) Aggregata sagittata n. sp. (Apicomplexa: Aggregatidae), a coccidian parasite from the European flying squid Todarodes sagitatus (Mollusca: Cephalopoda). Syst Parasitol 47:203-206

Gestal C, Guerra A, Pascual S, Azevedo C (2002a) On the life cycle of Aggregata eberthi and observation on Aggregata octopiana (Apicomplexa, Aggregatidae) from Galicia (NE Atlantic). Eur J Protistol 37:427-435

Gestal C, Abollo E, Pascual S (2002b) Observations on associated histopathology with Aggregata octopiana infection (Protista: Apicomplexa) in Octopus vulgaris. Dis Aquat Org 50:45-49

Gestal C, Páez de la Cadena M, Pascual S (2002c) Malabsorption syndrome observed in the common octopus Octopus vulgaris infected with Aggregata octopiana (Protista: Apicomplexa). Dis Aquat Org 51:61-65

Gestal C, Nigmatullin ChM, Hochberg FG, Guerra A, Pascual S (2005) Aggregata andresi n. sp. (Apicomplexa: Aggregatidae) from the ommastrephid squid Martialia hyadesi in the SW Atlantic Ocean and some general remarks on Aggregata spp. in cephalopod hosts. Syst Parasitol 60: 65-73

González AF, Guerra A, Pascual S, Briand P (1998) Vulcanoctopus hydrothermalis gen. et sp. nov. (Mollusca, Cephalopoda): an octopod from a deep sea hydrotermal vent. Cah Biol Mar 39:169-184

Hochberg FG (1990) Diseases of Mollusca: Cephalopoda. Diseases caused by protistans and metazoans. In: Kinne $\mathrm{O}$ (ed) Diseases of marine animals, Vol. III. Cephalopoda to 
Urochordata. Biologisches Anstalt Helgoland, Hamburg, p 47-227

Khan RA, Threlfall W, Whitty WS (1992) Hematozoa of deepsea demersal fish of the northwestern Atlantic Ocean. Can J Zool 70:1926-1933

Kopecná J, Jirku M, Miroslav O, Tokarec YS, Lukes J, Modrý D (2006) Phylogenetic analysis of coccidian parasites from invertebrates: search for missing links. Protist 157: 173-183

Labbé A (1895) Sur le noyau et la division nucléaire chez les Benedenia. C R Acad Sci Paris 120:381-383

Lom J, Dyková I (1992) (eds) Protozoan parasites of fishes. In: Developments in aquaculture and fisheries science, Vol. 26. Elsevier, London, p 1-315

Narasimhamurti CC (1979) The eimeriid Aggregata kudoi n. sp. from Sepia eliptica. Angew Parasitol 20:154-158

Poynton SL, Reimschuessel R, Stoskopf MK (1992) Aggregata dobelli n. sp. and Aggregata millerorum n. sp. (Apicomplexa: Aggregatidae) from two species of octopus (Mollusca: Octopodidae) from the eastern North Pacific Ocean. J Parasitol 39:248-256

Rocha F, González AF, Segonzac M, Guerra A (2002) Behavioural observations of the cephalopod Vulcanoctopus hydrothermalis. Cah Biol Mar 43:299-302

Sardella NH, Re ME (1988) Parasitosis por coccidios del gen-

Editorial responsibility: Eugene Burreson,

Gloucester Point, Virginia, USA ero Aggregata en pulpos costeros patagonicos. I. Aggregata sp. en Octopus tehuelchus d'Orbigny. Physis Secc A 46:51-60

Sardella NH, Ré ME, Timi JT (2000) Two new Aggregata species (Apicomplexa: Aggregatidae) infecting Octopus tehuelchus and Enteroctopus megalocyatus (Mollusca: Octopodidae) in Patagonia, Argentina. J Parasitol 86: 1107-1113

Schneider A (1875) Note sur le sporospermies oviformes du poulpe. Arch Zool Exp Gen 4:11-14

> Smit NJ, Davies AJ (2006) Desseria zei sp. nov. (Adeleorina: Haemogregarinidae) infecting Zeus capensis from deep waters off the south and west coasts of South Africa. J Mar Biol Assoc UK 86:1477-1480

Théodoridès J, Desportes I (1975) Sporozoaires d'invertébrés pélagiques de Villefranche-sur-Mer (étude descriptive et faunistique). Protistologica 1:205-220

Threlfall W, Khan RA (1990) Myxozoa of deep-sea fishes in the northwestern Atlantic. J Parasitol 76:288-290

> Voight JR (2005) Hydrothermal vent octopuses of Vulcanoctopus hydrothermalis feed on bathypelagic amphipods of Halice hesmonectes. J Mar Biol Assoc UK 85:985-988

Yoshino TP, Moser M (1974) Myxosporida (Protozoa) in macrourid fishes (Coryphaenoides spp) of the northeastern Pacific. J Parasitol 60:655-659

Submitted: April 14, 2010; Accepted: June 28, 2010

Proofs received from author(s): September 1, 2010 